\title{
Transatlantica
}

Revue d'études américaines. American Studies Journal

\section{Toni Morrison (1931-2019): Reaching toward the Ineffable}

\section{Claudine Raynaud}

\section{(2) OpenEdition \\ Journals}

Electronic version

URL: https://journals.openedition.org/transatlantica/14962

DOI: 10.4000/transatlantica. 14962

ISSN: 1765-2766

\section{Publisher}

Association française d'Etudes Américaines (AFEA)

\section{Electronic reference}

Claudine Raynaud, "Toni Morrison (1931-2019): Reaching toward the Ineffable", Transatlantica [Online], 2 | 2019, Online since 15 September 2020, connection on 01 February 2023. URL: http://

journals.openedition.org/transatlantica/14962 ; DOI: https://doi.org/10.4000/transatlantica.14962

This text was automatically generated on 1 February 2023.

\section{(c) (i) $\odot$}

Creative Commons - Attribution-NonCommercial-NoDerivatives 4.0 International - CC BY-NC-ND 4.0

https://creativecommons.org/licenses/by-nc-nd/4.0/ 


\title{
Toni Morrison (1931-2019): Reaching toward the Ineffable
}

\author{
Claudine Raynaud
}

Be it grand or slender, burrowing, blasting, or refusing to sanctify; whether it laughs out loud or is a cry without an alphabet, the choice word, the chosen silence, unmolested language surges toward knowledge, not its destruction. But who does not

know of literature banned because it is interrogative; discredited because it is critical; erased because alternate? And how many are outraged by the thought of a self-ravaged tongue?

(Stockholm lecture, 1993, D 203, italics mine) ${ }^{1}$

1 Toni Morrison, celebrated as the first African American woman to win the Nobel Prize for literature in 1993, died a year ago on August 5th, 2019. In one of her last interviews, she said that she wanted to outlive Donald Trump's presidency; she did not utter his name, referring to him as "number 45" (Busnel 2018). She was not granted her wish and one wonders what she would have said about the current pandemic, as it strikes the African American community in disproportionate numbers, as mass graves are dug in New York City's Hart Island while the world grieves, mourns, and watches in disbelief (Williams 2020). The May 25 murder of George Floyd by a white officer, caught on a bystander's smartphone, has led to week-long protests in 200 cities and the intervention of the national guard in 29 states on June $3^{\text {rd }}$ \#BlackLivesMatter, as its chanted motto proclaims, pursues Morrison's lifelong probing of "Black Matters" (PD 1-28); this surge of protests against the contemporary lynching of a black man brings to mind Guitar's words in Song of Solomon (1977): "It's not about you living longer. It's about how you live and why. It's about whether your children can make other children. It is about trying to make a world where one day white people will think before they lynch" (160). 
2 Signs had prepared the community of Morrison scholars to her departure, but it nonetheless came as a shock. We were used to her regular public appearances and interventions, to her laughter; she had embarked on a new novel that dealt with two young boys, one white and mute, the other black. "They become friends." She had also insisted that she was writing the best sex scenes ever, in all her novels. A documentary film, The Pieces I Am (2018), a collection of essays, interviews, and speeches, The Source of Self-Regard (2019), simultaneously published in England under the awe-inspiring title Mouth Full of Blood, had been the harbinger of her declining health. Preparing a major conference on Song of Solomon, her third novel, placed on the 2020 syllabus for the agrégation, we decided that we would celebrate her work in her absence. The Montpellier conference is now destined to turn into an homage, and doubly so, since Cheryl A. Wall, one of the leading scholars on African American women novelists, author of Women of the Harlem Renaissance (1995), and Worrying the Line (2005), died in April. Professor Wall was scheduled to give a talk on Morrison's "sublime word-work." Death, loss, vulnerability: a tryptic that runs through Morrison's oeuvre. Yet the email exchanges of the bereft all pointed to what Morrison has bequeathed us: her fighting spirit, her humor, her irony, in short, her work and the community of her readers, world-wide. The imperative of "response-ability" $(P D, \mathrm{xi})$, the urgency for love.

Rather than summarizing her life and listing her productions, I would like to address her legacy in terms of how she viewed language, how she understood writing, how she defined literary creation and imagination. I would also like to stress her political commitment. She maintained that "the best art is political, and you ought to be able to make it unquestionably political and irrevocably beautiful at the same time" (D 64). Morrison's aesthetics derives from and is one with her politics. In the fight against racism, the words of the public intellectual are an answer to a national emergency.

\section{"We do language" (D 203) $)^{3}$}

In her 1987 eulogy for James Baldwin, Morrison thanked him for having paved the way for a renewal of American English: "You gave me a language to dwell in, a gift so perfect it seems my own invention. In your hands language was handsome again. In your hands we saw what it was meant to be: neither bloodless nor bloody, and yet alive" (D 91). As she explains in the Stockholm lecture, language enables "to see without pictures" and "protects us from the scariness of things with no names" (D 206): it is both vision and bulwark. Language is a tool for change. The blind old woman of the fable stands in for the writer: "[s]he thinks of language partly as a system, partly as a living thing over which one has control, but mostly as agency-as an act with consequences" (D 200). This living thing must be freed from centuries of misuse for the black writer in the United States must first confront the racial character of the language at his/her disposal.

5 Morrison has attempted to write beyond race, to work on racial markers in her narratives to the point of erasing them. She did so in her short story "Récitatif" where she removed all racial codes about two characters of different races. The incipit of Paradise-"They shoot the white girl first" (3)-has the reader guessing who the white girl is, something purposely left unclear throughout the novel. This trick has him/her go back on his/her own racializing mind in a reflexive gesture that leads to a consciousness of the constructedness of racial categories. ${ }^{4}$ Morrison, however, admits 
failure when "imagining an un-raced figure [executing the murders]" (S xii) in the O. J. Simpson case. This catch-22 situation of aiming for the unraced while having at her disposal a language that carries and perpetuates a racial worldview explains the quality of her writing, its inner tensions. Furthermore, the black writer/white writer opposition and the question of belonging reverberates that conflict. In 2001, interviewed about race when it had been agreed that the encounter would be solely dedicated to an analysis of her work, she exclaims: "How novel it would be, if [...] I was not a (raced) foreigner, but a home girl, who already belonged to the human race" ( $\mathrm{S}$ 345). Excluded from humanity, yet having to endlessly discuss the terms of that exclusion. No wonder the outlaws, the pariahs, abound in her fiction as it probes the meaning of "home" and questions who the foreigner is. ${ }^{5}$

6 The language of the writer is that of her people whose variegated voices Morrison recreates in her novels-"I wanted to restore the language that black people spoke to its original power" (TG 121)-which accounts for the tension between the written and the spoken word in her writing. That contradiction between the letter and the spoken word, or literature and oral culture, is best exemplified by A Mercy where the slave girl Florens writes a letter to her lover, the illiterate African blacksmith: her words are partly the novel we have been reading when we close the book. Language, on the other hand, can only approach the Real of death and of trauma: "How can I say things that are images" (Beloved 210), exclaims the slave daughter on the slave ship. The unspeakable, the unnamable remains unspoken, unuttered. Like Sethe, moving about the room, unable to get to the heart of her murderous gesture, the reader understands that language falls short, falters, fails. Its limits are the child's babble, animal talk, or the cry uttered by Sula: "circles and circles of sorrow" (Sula 174). In its attempt to say the unsayable, language dons the qualities of jazz blue notes: "Language can never 'pin down' slavery, genocide, war. Nor should it yearn for the arrogance to do so. Its force, its felicity, is in its reach toward the ineffable" (D 203).

\section{"A rememory that belongs to somebody else" (Beloved 36)}

7 Two major essays let the readers approach the genesis of Morrison's creative imagination: "Memory, Creation and Fiction" (1984) and "The Site of Memory" (1995). She has commented on the incipits of her own novels in the lectures "Unspeakable Things, Unspoken: The African American Presence in American Literature" (1989). Creation is linked to memory or "the deliberate act of remembering" that she defines as "a form of willed creation" (D 70). The slave narratives that are at the source of the African American literary tradition do not give access to the slaves' psyches. As abolitionist propaganda and directed to a white audience, they themselves signaled that they would not report "proceedings too terrible to relate" (D 70) and spared their readers "from motives of delicacy." Morrison sees her task as "ripping the veil" drawn over these unspeakable acts and giving access to the "inner lives" of the slaves. Investing the blanks left by the narrators of the slave narratives, she gives the world Beloved, her novel of slavery. It does not deal with "slavery with a capital S, but with "these anonymous people called slaves" (TG 257). She also wanted to reader to be "yanked" back to those times, kidnapped as the slaves were. 
The time of Beloved is that of Reconstruction (1865-1877): the Peculiar Institution is evoked through the memories of the ex-slaves, Sethe and Paul D, of the Sweet Home plantation. Remembering-Morrison uses the African American word "rememory" as a verb and a noun-is impossible, and at the same time, necessary in order to make peace with the past. Sethe's definition of her "rememory" makes clear that it is a "thought picture," out there, linked to the soil, as if Morrison had literalized the expression lieu de mémoire, site of memory: "It's so hard for me to believe in [time]. Some things go. Pass on. Some things just stay. I used to think it was my rememory... But it's not. Places, places are still there. If a house burns down, it's gone, but the place-the picture of itstays, and not just in my rememory, but out there, in the world" (Beloved 36). Rememory figures the return of the repressed, but it also covers the collective past in its articulation to individual memory: "rememory as in recollecting and remembering as in reassembling the members of the body, the family, the population of the past" ( $\mathrm{S}$ 324). Sethe insists that even if the farm where she was enslaved dies, "the picture is still there and what's more, if you go there-you who was never there-if you go there and stand in the place where it was, it will happen again; it will be there for you, waiting for you" (Beloved 36).

9 The genesis of a novel, or a scene, is often an image that stems from a recollection; Morrison moves from the image to the text, not the other way around. The distinction that is operative for her is that between facts and truth, not that between fact and fiction. Unlike facts, truth requires human intelligence. For Beloved, she relied on a childhood memory and the image that recurred in her mind led her to reconstruct the love scene between Sethe and Halle, through Paul D's recollection. The metaphor of archeological reconstruction translates her links to the memory of her parents, her grandparents, her great-grandmother:

These people are my access to me; they are my entrance into my own interior life. Which is why the images that float around them-the remains so to speak, at the archeological site-surface first, and they surface so vividly and so compellingly that I acknowledge them as my route to a reconstruction of a world, to an exploration of an interior life that was not written and to the revelation of a kind of truth. (D 74)

The metaphor of archeology also recurs in psychoanalysis to explain Freud's theory of memory and the Unconscious.

\section{“History as life lived" (D 36)}

10 The link to history, and more specifically the effort of rewriting American history from the point of view of those excluded, or even erased from official records, is a constant throughout her output: "A major part of American history is the history of Black people: how they influenced whites and how whites influenced them" (D 48). The Black Book (1974), a scrapbook of newspaper clippings, songs, whose production she supervised when she was editor at Random House is at the genesis of two of her novels: Beloved and Jazz. Its fragmentation and up-hazard nature also correspond to the aesthetics of her novels. History must be the record of the lives of ordinary people:

Because our children can't use and don't need and will certainly reject history-asimagined, they deserve better: history as life lived. [...] Historians must necessarily speak in generalities and must examine recorded sources: statistics on income earned, books by activists and leaders, dates, etc. ... They habitually leave out life 
lived by everyday people. [...] But artists don't have any such limitations, and as the truest of historians, they are obligated not to. (D 36-37)

11 Margaret Garner was a slave who killed her daughter and injured her other children rather than have them return to slavery. What struck Morrison when she read the reports is the slave woman's composure. She had made a choice; she was not a victim. The killed daughter comes back to ask for retribution. To Morrison, the artists recreate on the page the way in which the downtrodden, "the disremembered and unaccounted for" (Beloved 275) have experienced their lives. How they ate, loved, and slept-their material lives, and how they survived in terrible circumstances. She refuses the myths of black nationalists, among them the "Black is Beautiful" slogan, a reactionary gesture: "when the focus is turned to how one looks as opposed to what one is, we are in trouble" (D 38). In view of the changes brought about by the Civil Rights movement, she insists that "the deeper the conviction that something valuable is slipping away from us, the more necessary it has become to find some way to hold on to the usable past without blocking off the possibilities of the future" (D 42). Because History is written by the victors, she must rely on memory, her memory, but also the memory of others for "[s]o much Black history and art is not reinterpretation or reevaluation as it should be" (D 36). Yet she refuses to see Black history as a litany of horrors: "There is repetition of the grotesque in our history. And there is the miraculous walk of trees. The question is whether our walk is progress or merely movement" (D 8).

\section{"A disturbing disturbance" (D 33)}

Morrison's relation to feminism is akin to her position vis-a-vis black nationalism: she is wary of labels. She writes from her point of view, that of a black woman. Contrary to the white woman, the black woman has always worked. As time frames, modernism and postmodernism do not apply to her experience: “From a woman's point of view, in terms of confronting the problems of where the world is now, black women [have] had to deal with 'postmodern' problems in the nineteenth century and earlier" (Gilroy 178). Morrison's novels, with the exception of Song of Solomon, focus on women: mothers, daughters, generations of women that reflect her own household, with the female ancestor-Eva, Pilate, Baby Suggs, Olive-occupying a prominent place. A character, the sexually abused little black girl, recurs from The Bluest Eye to God Help the Child, the most vulnerable creature of all. In Beloved, she is the slave daughter in the hold of the ship who thinks unuttered thoughts. In A Mercy, she suffers her mother's abandonment; in Home, she is Cee, the unborn child Cee's barren womb (after the white eugenicist's experiments) will not bear, and the little girl Cee's brother shot in the Korean War.

"The Black woman" does not exist: "it is a dangerous misconception" (D 19), Morrison proclaims since experiences vary, individuals differ. She also deconstructs the manmade stereotypes of Geraldine from The Flip Wilson show and Sapphire from Amos ' $n$ ' Andy and qualifies black women as follows: "If she was a sexual object in the eyes of men, that was their doing. Sex was one of her dimensions. It had to be just one, for life required many other things of her and it is difficult to be regarded solely as a sex object, when the burden of field and fire is on your shoulders" (D 25). Asked about how black women felt about the Women's Liberation movement in 1971, Morrison bluntly answered that they distrusted it (D 20). In a long piece on "Women, Race and Memory," she categorizes feminists into three groups: radical feminists, anti-feminists, and 
nonaligned feminists and denounces the divisiveness brought about by female saboteurs. Male supremacy will collapse with the attack on racism and class hierarchy: "Pretending that racist elements in male supremacy are secondary to sexism is to avoid, once again, the opportunity to eradicate sexism completely" (S 93). Harriet Tubman's fight to be recognized as cook, nurse, and soldier frames the essay, an example of a multitasking black woman who fought the white male-dominated world, and won.

The differences between black and white women naturally extend to the writers of both races:

It seems to me there's an enormous difference in the writing of black and white women. Aggression is not as new to black women as it is to white women. Black women seem able to combine the nest and the adventure. They don't see conflicts in certain areas as do white women. They are both safe harbor and ship; they are both inn and trail. We, black women, do both. (TG 161)

Morrison has also explained that, as a black woman writer, she was free of the white gaze that she felt encumbered black male writers who, in their works, reacted to their white counterparts. Her imagination was thus unhampered. That freedom she wished to share with her sisters in a poetic address which heralds the black woman's advent: "There is a movement in the shadow of a sun that is old now. There, just there. Coming from the rim of the world. A disturbing disturbance that is not a hawk nor stormy weather, but a dark woman, of all things; My sister, my me-rustling, like life" (D 33).

\section{"In the beginning was the sound" (Beloved 259)}

Morrison's effort as a writer is to restore the orality of the black vernacular in the written text. Cleansed of any excess, words should be performed: "The language must be careful and must appear effortless. It must not sweat. It must suggest and be provocative at the same time. It is the thing that black people love so much-the saying of words, holding them on the tongue, experimenting with them, playing with them" (TG 123). Her dialogues have the power of the spoken exchanges in the street, the kitchens, the barbershops, or the poolhalls of black people. The folk idiom, the black vernacular, the verbal ritual of the dozens, as much as the voices that sing or just speak their interior monologues are a means of preserving the oral/aural characteristics of black art. Her novels are a polyphony of different voices that can culminate in a chant, as is the case in Beloved when the prose narrative gives way to a threnody, an unuttered dialogue. The mother, Sethe, and the two daughters, Denver and Beloved, the dead one and the ghost, unite their voices. The printed words on the page and the narrative mode give way to singing, in which voices can overlap and mix.

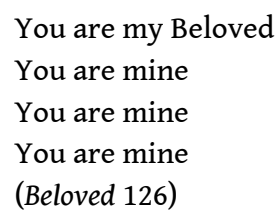

16 Jazz (1992) is composed like a musical piece with the melody recurring, going away, coming back: "I thought of the plot in that novel-the threesome-as the melody of the piece, and it is fine to follow a melody-to feel the satisfaction of recognizing a melody whenever the narrator returns to it. That was the real art of the enterprise for mebumping up against that melody time and again, seeing it from another point of view, 
seeing it afresh each time, playing it back and forth" (Schappell 1993). The jazzlike text duplicates music's syncopation, its improvisational nature.

While including references to history, Morrison's novels also abound in "supernatural" elements which has led some critics to label her novels "magic realism." Yet this worldview is that of her culture:

of course, that (i.e. "spiritual forces") is the reality [...] It's what informs your sensibility. 1 grew up in a house in which people talked about their dreams with the same authority that they talked about what "really" happened. They had visitations and [...] some sweet, intimate connection with things that were not empirically verifiable. [...] Without that, I think I would have been quite bereft because I would have been dependent on so-called scientific data to explain hopelessly unscientific things [...]. (Gates 415)

Folk knowledge has been discredited, along with the people who had forged it: "If my work is to confront a reality unlike that received reality of the West, it must centralize and animate information discredited by the West" (S 267). The specificity of the culture of reference does not preclude surrendering the universal appeal of her work, quite the contrary: "I write what I have recently begun to call village literature, fiction that is really for the village, for the tribe. Peasant literature for my people, which is necessary and legitimate but which also allows me to get in touch with all sorts of people" (TG 120-121). She points out that Tolstoy could write about the Russian peasantry, which did not prevent him from attracting a global readership. Such assumptions speak to the racialized appreciation of African American literature treated as sociology, and not art. Toni Morrison's particular aesthetics rests on qualities that stem from vernacular culture: "If my work is faithfully to reflect the aesthetic tradition of Afro-American culture, it must make conscious use of the characteristics of its art forms and translate them into print: antiphony, the group nature of art, its functionality, its improvisational nature, its relation to audience performance [...]" (S 331).

\section{"Lynching [...] is also the metaphor of itself" (Morrison 1997 11)}

The novels should not be divorced from Morrison's political engagement and her involvement in the debates that raged and crystallized around two causes célèbres for she stresses that "the thoughts, the insights, the analyses of academics in a variety of disciplines" are essential (Morrison 1992c 4). The nomination in 1991 of Clarence Thomas, a conservative black judge, to the Supreme Court to succeed Thurgood Marshall led to a much-publicized confrontation when a conservative black lawyer, Anita Hill, accused Thomas of sexual harassment. The ingredients of sex and race, and the voyeurism of the whole nation that followed the confirmation hearings leads Morrison to state that "as is most always the case, the site of the exorcism of critical national issues was situated in the miasma of black life and inscribed on the bodies of black people" (Morrison 1992c 4). Her close textual analysis of the comments made on both Hill and Thomas unveils their racist slant, uncovers the persistent stereotypical opposition of docility vs bestiality, and the mechanical link of the single black individual to "race" as a whole. The day of the week of the hearings, Friday, leads to her development on Crusoe's Friday who, internalizing the master's tongue, is condemned, because he was rescued, to adore his master. This essay is a demonstration of Morrison's skill at its most efficient: it conjures British colonial history, literature 
(Defoe), and weaves an analogy that makes the reader understand how both Thomas and Hill are embroiled in implacable racial readings. As a way out of these, Morrison stresses the necessity of remaining in touch with one's original culture and the dire consequences of losing the mother tongue. She also welcomes this moment of intersectional reckoning, as the title of the collection of essays to which she contributed, but that she also edited and introduced, makes clear: Raceing Justice, Engendering Power: Essays on Anita Hill, Clarence Thomas and the Construction of Social Reality.

O. J. Simpson's trial in 1994-1995 was televised for all America to watch a black football legend and actor accused of the murder of his white wife and her male friend. Morrison returns to Melville's Benito Cereno and the impossibility for the racial mind of thinking the agency of the black subject: "For centuries, the debate in human versus animal discourse has rested on blacks, thus relegating to them the essence of contradiction" (Morrison $1997 \mathrm{xi}$ ). Morrison explicates in detail how the official story about Simpson, with the complicity of the media, blocks the emergence of counter-stories. As in Melville's text, the axis of the narrative is race: "The Simpson spectacle has become an enunciation of post-Civil Rights discourse on black deviance" (Morrison 1997 xxvii). Reason and objectivity are dispensed with, at the same time as the burden of representativity falls on the black person. Morrison repeatedly points out the overdetermination of/in discourse, the impossibility of imagining, and hence writing, an un-raced subject. She closes her preface to Playing in the Dark as follows: "Living in a nation of people who decided that their world view would combine agendas for individual freedom and mechanisms for devastating racial oppression presents a singular landscape for the writer" (PD xiii). Liberty and slavery at the foundation of the nation, with an uninterrupted four century-long "national amnesia" (TG 257) about the Peculiar Institution.

Since her books are censored in some states, ${ }^{6}$ Morrison addressed that issue when she edited Burn this Book. Notes on Literature and Engagement (2009). Side by side with Salman Rushdie at the Parliament of Writers, she voiced her outrage at the slaughtering of writers, the arresting of poets by authoritarian regimes, at the suppression, the banning of books: "Efforts to censor, starve, regulate or annihilate us are clear signs that something important has taken place" (S viii). Literature is not a gift; it is a necessity, for writers also come under the threat of death.

\section{“Look where your hands are now" (Jazz 229)}

21 Morrison has always contested the concept of the individual artist. Writing means creating a bond with her readers who participate in the creation of the book: "It is our book" (Busnel 2018). The blind old woman of the Nobel lecture closes her speech to the young men as follows: "Look. How lovely it is, this thing we have done-together" (D 207). Placing her creation in continuity with the black sermon or the jazzman's music, she provides "the places and spaces so that the reader can participate." (D 59). The chorus is present in the novels (the community, but also the narrator-the I of The Bluest Eye-standing in for the one who watches, reacts, comments). The reader sees her reflection in this diffracted choral response. The relation between reading and writing, that Roland Barthes theorized in $S / Z$, the reader being a "producer of the text," is understood by Morrison, a long-time editor and professor of literature, as an encounter, a dance of open minds: 
Writing and reading are not that distinct for a writer. Both exercises require being alert and ready for unaccountable beauty, for the intricateness or simple elegance of the writer's imagination, for the world that imagination evokes. Both require being mindful of the places where imagination sabotages itself, locks its own gates, pollutes its vision. Writing and reading mean being aware of the writer's notions of risk and safety, the serene achievement of, or sweaty fight for, meaning and response-ability. (PD xi)

The reader is the text's other in a dialogue of creation, in an engagement of two interacting imaginations, one responding sensorially, bodily, to the other. Reading is "the intimate, sustained surrender to the company of [her] own mind while it touches another's" (D 190). Her first endeavor was to write a book, The Bluest Eye (1970), because she could not find one to read about little black girls that she could relate to:

I was writing for some clear, single person-I would say myself, because I was quite content to be the only reader. I thought that everything that needed to be written had been written: there was so much. I am not being facetious when I say I wrote it in order to read it. And I think that is what makes the difference, because I could look at it as a reader, really as a reader, and not as my own work. (Morrison 1980)

This process of estrangement from her own output speaks to her work as editor at Random House (1970-1988). She published a number of leading black figures and writers: Angela Davis, Muhammad Ali, Toni Cade Bambara, Gayl Jones, Leon Forrest, June Jordan, and Andrew Young. It also calls forth the role of the reader as the other doer/agent of the literary text. Her editorial role once again asserts the dialogic interaction at the heart of her literary production.

\section{"Pondering color" (Beloved 4)}

23 Morrison's readings of the presence of the African in the works of Melville, Twain, Faulkner, Hemingway, or Willa Cather enables her to open up a new area of investigation in literary criticism: the role played by the racial imagination in the production of these major canonical American writers. The presence of the black man as the "ghost in the machine," and the concomitant corresponding creation of "literary whiteness" are the subject of those 1992 Harvard lectures which she then pursued under the title The Origin of Others in 2017. In these essays, she investigates the link between "race," the claim to universalism, and the creative imagination:

What does positing one's writerly self, in the wholly racialized society that is the United States, as unraced and the others as raced entail? What happens to the writerly imagination of a black author who is at some level always conscious of representing one's own race to, or in spite of, a race of readers that understands itself as "universal" or race-free? In other words, how is "literary whiteness" and "literary blackness" made, and what is the consequence of that construction? (PD xii)

Her close textual studies means tracking the way in which "blackness" is depicted: “'Africanism' [she uses as] a term for the denotative and connotative blackness that African peoples have come to signify, as well as the entire range of views, assumptions, readings, and mis-readings that accompany Eurocentric learning about these people" (PD 6-7). Following in Baldwin's footsteps, when he famously reversed the question of the 'black problem' into a white problem, she summarizes her critical endeavor as follows: "In no way do I mean an investigation of what might be called racist or nonracist literature. [...] My project is an effort to avert the critical gaze from the racial object to the racial subject; from the described and imagined to the describers and 
imaginers; from the serving to the served" (PD 90). What needs to be studied is "the impact of racism on those that perpetuate it" (PD 11), not those who have been othered. Hers is no Manichean pursuit, but rather the mapping of a new intellectual field of inquiry. The historian Nell Irving Painter credits Morrison for launching what has been called "Whiteness Studies."

\section{"Sharpening the moral imagination" (S ix)}

In 2018, to the question "What is the role of literature?" Morrison answered:

There is an element of pleasure, and apprenticeship, and then, there's wisdom: [...] literature gives access to all that. I believe it sheds light on what humans are made for, for a certain level of intelligence, and love, and link building, without hostility, without, you know, pushing [...] aside. It's a little idealistic. [...] So what? [...] I don't want to go the other way. [...] It's real. Life is real, and our experiences, also. Novels, fiction are all my life, where I live, and what make me, like the others, and unlike the others, at the same time. This is what this art is for me. (Busnel 2018) ${ }^{7}$

Writers alone can make sense of extreme suffering: "Certain kinds of trauma are so deep, so cruel, [...] only writers can translate such trauma and turn sorrow into meaning" (S ix). Beyond providing meaning, stories, or rather storytelling, is a way of knowing: "Narrative is one of the ways in which knowledge is organized" (S 330). Literature is knowledge. Fiction helps access an understanding that the simple statement of facts does not permit. In the same way as she sometimes withholds racial identity, Morrison withdraws gender markers in the liminal pages of Love, or in Jazz, where the Voice of the City is a man or a woman. She writes in invisible ink: "Invisible ink is what lies under, between, outside the lines, hidden until the right reader discovers it" (S 348). The unwritten subtext matters as much as the "choice word;" the "chosen silence" is a willed absence, a programmed lack, beckoning to the reader. Morrison has also stated, with a chuckle: "I think, therefore I write" (Busnel 2017). When reading her writing, the active engagement of the reader means entering the interior lives of her characters, viewing the world through their eyes and, more crucially, partaking in their emotions, feeling rather than viewing. Morrison trusts her reader to bring to the text his/her own imagination and for him/her to do so, she foregoes the explicit. Her novels are increasingly shorter as a result, contributing to a minimalist aesthetics.

The aim of her intervention is the healing of her community, a healing that the traditional arts of the African American people performed, and that is sorely needed now. Her writing enacts a transformation: "I write what could be called the tragic mode in which there is some catharsis and revelation" (TG 125). For the most part, the shorter novels of the later period-Home (2002), A Mercy (2008), God Help the Child (2015) -stage the performance of that healing: Frank and Cee Money, the siblings of Home (2012), are re-united and give a proper burial to the black man that they had witnessed in their childhood, as his lynchers threw him into an unmarked grave. Bride and Booker, the estranged lovers of God Help the Child, start a family. In Beloved, the exchange between Paul D and Sethe helps Sethe come to terms with her trauma and word the killing of her child as a decision to spare the latter from worse atrocities than death. Paul D's desire to "put his story next to hers" (Beloved 273), at the close of the text, highlights the novel's texture as interlacing stories on which the characters literally feed, as should the reader. The ambiguous ending can serve as a metonym for 
the motion that animates Morrison's fiction, from the vulnerability of memory to glimmerings of hope: it tells "the essence of memory turned to nostalgia and regret and moving forward finally towards a very thin, but not so frail, possibility of hope for the future" (S 325).

\section{"The uncapturability of the life that it mourns (D 203)}

Reflecting on Lincoln's Gettysburg address and the dead of the Civil War, mourning the dead of 9/11, alerting us to the fact that language is "susceptible to death, erasure" (D 200), Morrison's interventions both signal that language, like memory, fights absence and loss. But she also insists that it can be "dumb, predatory, sentimental" (D 200). Even in its death throes, it might still "thwart intellect, stall conscience, suppress human potential" (D 200). Rejecting the policing languages of mastery, she maintains that language is a living thing, a bird in our hands. Shall we choke it or let it fly? In A Mercy, the words of the slave daughter carved on the walls of the white farmer's house will be talking to each other, she assumes, once the door is shut; but another future emerges: "Perhaps these words need the air that is out in the world. Need to fly up then fall, fall like ash over acres of primrose and mallow. Over a turquoise lake, beyond the eternal hemlock, through the clouds cut by rainbow and flavor the soil of the earth. Lina will help" (A Mercy 161). Flying words that, with the Native woman's help, fertilize the earth, or literature as life-giving (once the dead white master's deserted house has been set on fire?)-assuredly, the promise of a shareable world in a common language, the possibility of a human future.

\section{BIBLIOGRAPHY}

BARTHES, Roland. S/Z. Paris: Éditions du Seuil, 1970.

BUSNEL, François. "Entretien exclusif avec la romancière américaine Toni Morrison." La Grande Librairie, TV 5, April 7th, 2017. https://www.youtube.com/watch?v=nSeR0uHg68Y. Accessed 26 September 2020.

BUSNEL, François. "Rencontre exceptionnelle avec Toni Morrison à New York." La Grande Librairie, TV 5, April 20th, 2018. https://www.youtube.com/watch?v=8HLtcRcD7ws. Accessed 26 September 2020.

DENARD, Carolyn, ed. What Moves at the Margin: Selected Nonfiction. Jackson, MI: University of Mississippi Press, 2008.

GATES, Henry Louis, Jr. and Anthony Appiah, eds. Toni Morrison. Critical Perspectives: Past and Present. New York: Amistad, 1993.

GILROY, Paul. "Living Memory: A Meeting with Toni Morrison." Small Acts, Thoughts on the Politics of Black Cultures. London: Serpent's Tail, 1993, 175-182. 
GREENFIELD-SANDERS, Timothy. ed., Toni Morrison: The Pieces I Am. With Toni Morrison. Oprah Winfrey, Hilton Als, 2019.

JABALI, Malaika. "The coronavirus has laid bare the reality of America's racial caste system." The Guardian, May $27^{\text {th }}, 2020$. https://www.theguardian.com/commentisfree/2020/may/27/ coronavirus-america-racial-caste-system. Accessed 26 September 2020.

MORRISON, Toni. “Two Major Events of the Year: The Visits of Writers Toni Morrison and Eudora Welty.” Bryn Mawr Alumnae Bulletin, Spring 1980.

MORRISON, Toni. Playing in the Dark. Whiteness and the Literary Imagination. Cambridge Harvard University Press, 1992a.

MORRISON, Toni. Beloved. New York: Knopf, 1987.

MORRISON, Toni and Claudia Brodsky Lacour, eds. Birth of a Nation'hood: Gaze, Script, and Spectacle in the O. J. Simpson Case. New York: Pantheon Books, 1997.

MORRISON, Toni. The Bluest Eye. New York: Holt, Rinehart \& Winston, 1970.

MORRISON, Toni. Invitée au Louvre. Étranger chez soi. Paris: Musée du Louvre, Titre 22, 2006.

MORRISON, Toni. God Help the Child. New York: Knopf, 2015.

MORRISON, Toni. Home. New York: Knopf, 2012

MORRISON, Toni. Jazz. New York: Knopf, $1992 b$.

MORRISON, Toni. Love. New York: Knopf, 2003.

MORRISON, Toni. A Mercy. New York: Knopf, 2008.

MORRISON, Toni. The Origin of Others. Cambridge, Mass.: Harvard UP, 2017.

MORRISON, Toni. Paradise. New York: Knopf, 1998.

MORRISON, Toni, ed. Race-ing Justice, En-Gendering Power. Essays on Anita Hill, Clarence Thomas, and the Construction of Social Reality. New York: Pantheon Books, 1992c.

MORRISON, Toni. Song of Solomon. New York: Knopf, 1977.

MORRISON, Toni. The Source of Self-Regard. Selected Essays, Speeches, and Meditations. New York: Knopf, 2019.

MORRISON, Toni. Sula. New York: Knopf, 1974.

SCHAPPELL, Elissa and Claudia Brodksy Lacour, interviewers. "Toni Morrison. The Art of Fiction No 134," Paris Review 128, Fall 1993. https://www.theparisreview.org/interviews/1888/the-art-offiction-no-134-toni-morrison

TAYLOR-GUTHRIE, Danille. Conversations with Toni Morrison. Jackson: University Press of Mississippi, 1994.

WALL, Cheryl A. Worrying the Line: Black Women Writers, Lineage, and Literary Tradition. Chapel Hill: U of North Carolina P, 2005.

WALL, Cheryl A. Women of the Harlem Renaissance. Bloomington: Indiana UP, 1995.

WILLIAMS, Vanessa. "Disproportionately black counties account for over half of coronavirus cases in the U.S. and nearly $60 \%$ of deaths, study finds." Washington Post, May $6^{\text {th }}, 2020$. https:// www.washingtonpost.com/nation/2020/05/06/study-finds-that-disproportionately-black- 
counties-account-more-than-half-covid-19-cases-us-nearly-60-percent-deaths/ Accessed 26 September 2020.

\section{NOTES}

1. Hereafter references to the essays and speeches in Denard 2008 will be abbreviated as D followed by the page number, the interviews in Taylor-Guthrie 1994 as TG, those in Morrison 2019 as S and the lectures in Morrison 1992a as PD.

2. Cheryl Wall had borrowed her title from Morrison's Stockholm lecture: "Word-work is sublime [...] because it is generative: it makes meaning that secures our difference, our human differencethe way in which we are like no other life." (D 203).

3. The full quotation reads: "We die. That may be the meaning of life. But we do language. That may be the measure of our lives." (D 203).

4. About Faulkner's Absolom! Absolom!, she notes: “As a reader you have been forced to hunt for a drop of black blood that means everything and nothing. The insanity of racism. So the structure is the argument" (Schappell 1993).

5. Morrison curated a series of events (lectures, concerts, an exhibition) at the Louvre entitled The Foreigner's Home (2006).

6. In 2017, Fairfax County (Virginia) drafted legislation known as the "Beloved Bill" that would prohibit teaching books with sexual content in public schools.

7. The excerpt is at 9:40; the translator's voice occasionally blurs access to Morrison's words. I have transcribed them as best as I could, relying at times on the translation.

INDEX

Subjects: Reconnaissances

\section{AUTHOR}

CLAUDINE RAYNAUD

Université Paul-Valéry Montpellier 